\title{
Nitrogen and Potassium Dynamics in Tea Cultivation as Influenced by Fertilizer Type and Application Rates
}

\author{
Kibet Sitienei ${ }^{1,2 *}$, Patrick G. Home ${ }^{2}$, David M. Kamau ${ }^{1}$, John K. Wanyoko ${ }^{1}$ \\ ${ }^{1}$ Tea Research Foundation of Kenya, Kericho, Kenya; ${ }^{2}$ Biomechanical and Environmental Engineering Department of Jomo Kenyatta \\ University of Agriculture and Technology, Nairobi, Kenya. \\ Email: ${ }^{*}$ sitnei@yahoo.com
}

Received October $7^{\text {th }}, 2012$; revised November $7^{\text {th }}, 2012$; accepted December $12^{\text {th }}, 2012$

\begin{abstract}
As the most important cultural practices for tea production, single effects of nitrogen $(\mathrm{N})$ and potassium $(\mathrm{K})$ fertilization on yield are well documented but their dynamics are poorly understood. It was necessary therefore to assess the dynamics of nitrogen and potassium in tea cultivation environment as influenced by fertilizer application rates. This objective led to a comprehensive field investigation in strongly acidic soils tea plots at Tea Research Foundation of Kenya, Kangaita substation in Kerugoya using clone TRFK 11-4 in a $3 \times 3, \mathrm{~N} \times \mathrm{K}$ factorial RCB design. Treatments were nitrogen $\left(0,100\right.$ and $\left.200 \mathrm{Kg} \mathrm{N} \cdot \mathrm{ha}^{-1} \cdot \mathrm{yr}^{-1}\right)$ as urea and potassium $\left(0,40\right.$ and $\left.80 \mathrm{Kg} \mathrm{K}_{2} \mathrm{O} \mathrm{ha}{ }^{-1} \cdot \mathrm{yr}^{-1}\right)$ as Muriate of potash (MoP) replicated thrice. Tea yield, plant biomass and plant nutrient concentrations were measured for calculation of plant nutrient uptake. Nutrients accumulated in the plants and removed from harvest were considered as nutrient loss, while fertilizer was considered as nutrient inputs gain to soil. In the interaction, there was no much difference between $\mathrm{N}-\mathrm{K}$ treatments and crop $\mathrm{N}$ removal except mature and maintenance leaves, but there was a positive linear relationship between $\mathrm{N}$ applied and the yield of made tea and negative linear relationship between $\mathrm{K}$ applied and yield of made tea. The results from the study also showed that fertilizer inputs generally surpassed the crop nutrient demands (nutrient loss from harvest).
\end{abstract}

Keywords: Camellia sinensis (L.); Dynamics; Clones; Concentration; Nutrient Removals

\section{Introduction}

Tea (Camellia sinensis), is one of the most important perennial crops in the highlands of Kenya. It is a significant cash crop used for domestic consumption and export.

Nitrogen is a critical nutrient for tea production, but it is difficult to optimize nitrogen $(\mathrm{N})$ fertilizer applications because of the dynamic nature of plant-available $\mathrm{N}$ over the growing season. Nitrogen is used in the production of protoplasm, proteins and chlorophyll and is the primary building block for all plant parts. Nitrogen availability affects yield of tea. Nitrogen applications should be carefully managed, particularly in tea, to optimize marketable yield while minimizing environmental effects. Yields increase with increasing use of nitrogen up to high levels with proportional increase in economic returns. Optimal $\mathrm{N}$ rates of tea vary depending on clones and location and range from 75 to $150 \mathrm{Kg} \mathrm{N} / \mathrm{ha}^{\prime} \cdot \mathrm{yr}^{-1}$.

Potassium is the most important cation not only in regard to its content in plant tissues but also with respect to its physiological and biochemical functions [1].

As an enzyme activator, potassium has been implicated

${ }^{*}$ Corresponding author. in over 60 enzymatic reactions, which are involved in many processes in the tea plant such as photosynthesis, respiration, carbohydrate metabolism, translocation and protein synthesis $[2,3]$. Tea has a moderate to high requirement for potassium and large amounts are removed in the leaf, thus depleting soil reserves.

Tea is the leading cash crop in Kenya, grossing over Ksh. 109 billion in 2011 [4]. Nitrogen management recommendations must be based not only on yields and economics, but also on environmental considerations. Understanding $\mathrm{N}$ and $\mathrm{K}$ dynamics under typical production practices may lead to best management practice recommendations that balance agronomic, economic, and environmental considerations. The objectives of this study were to assess Nand $\mathrm{K}$ dynamics in teacultivation in respect to 1) the rates of $\mathrm{N}: \mathrm{K}$ fertilizers application; and 2) total $\mathrm{N}$ and $\mathrm{K}$ budget.

\section{Materials and Methods}

\subsection{Research Site and Cultivar}

This research was conducted at Tea Research Foundation of Kenya, Kangaita substation in Kirinyaga (Figure 1). 


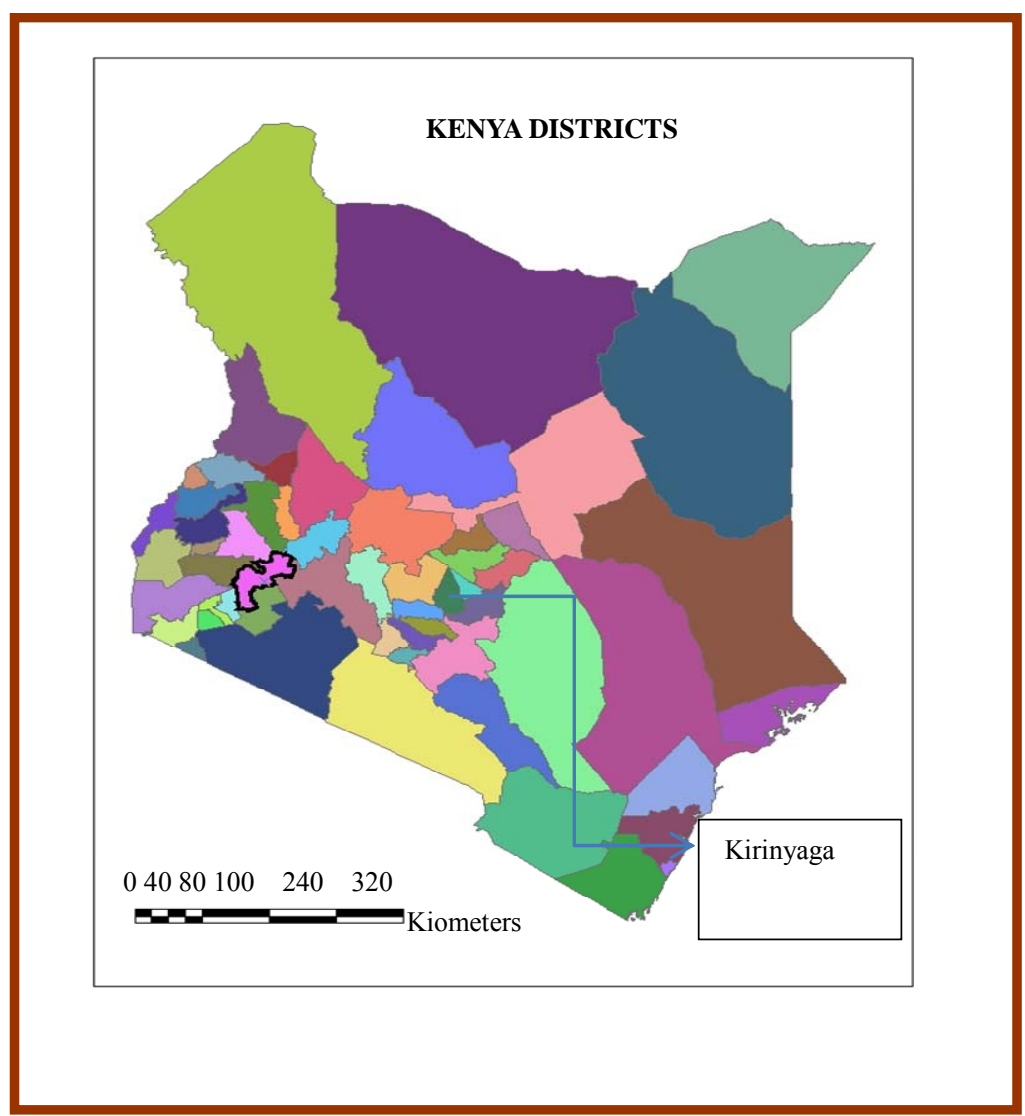

Figure 1. Location of kirinyaga (shaded dark green).

Kangaita $\left(37^{\circ} 17.8^{\prime} \mathrm{E} ; 0^{\circ} 19.8^{\prime} \mathrm{S} ; 2130\right.$ m.a.s.l.) is located on the slopes of Mount Kenya.

The soils in the study site are reasonably uniform, have characteristic red clay humic loam, and are strongly acidic. These soilsare classified as acrisols. The field was planted with tea clone TRFK 11-4 at a spacing of $1.22 \mathrm{~m}$ by $0.61 \mathrm{~m}$ ( $4 \mathrm{ft}$. by $2 \mathrm{ft}$.) rectangular. Field site was selected based on fertilizers types i.e. urea $(46 \% \mathrm{~N})$ and muriate of potash $(\mathrm{MoP}, 60 \% \mathrm{~K})$.

\subsection{Experiment Design}

A randomized complete block design with three replications was used for the study. The treatments were nitrogen rates $\left(0,100\right.$ and $\left.200 \mathrm{Kg} \mathrm{N} \cdot \mathrm{ha}^{-1} \cdot \mathrm{yr}^{-1}\right)$ and potassium rates $\left(0,40\right.$ and $\left.80 \mathrm{Kg} \mathrm{K}_{2} \mathrm{O} \mathrm{ha}{ }^{-1} \cdot \mathrm{yr}^{-1}\right)$. The sources of $\mathrm{N}$ and $\mathrm{K}$ were urea $(46 \% \mathrm{~N})$ and muriate of potash $(\mathrm{MoP}$, $60 \% \mathrm{~K}$ ) respectively. All of $\mathrm{N}$ and $\mathrm{K}$ were either applied at once or one after the other.

Soil and plant samples were collected in Aprilof 2011, while yield data were recorded monthly. Plant densities were similar in all plots i.e. each plot consisted of 150 bushes while the sub-plot consisted of 50 bushes. Plucking of tea was done in conformity with Kenya Tea Development Agency's (KTDA) standard practice, where two leaves and a bud were removed every ten to fourteen days and yield data were recorded monthly.

\subsection{Micro-Meteorological Variations}

The local climate is humid subtropical with annual rainfall which ranges between $1700-2150 \mathrm{~mm}$ while temperature ranges between $14.5^{\circ} \mathrm{C}-17.8^{\circ} \mathrm{C}$. Long rains start in mid-march while short rains start in mid-October. A summary of the major values of micro-meteorological parameters during the experimental periods is shown in Table 1.

\subsection{Soil and Plant Tissue Measurements}

In each plot, soils were core sampled at root zone depth intervals of $0-10,10-20,20-30$ and $40-60 \mathrm{~cm}$ for physical and chemical analyses.

Tissues samples were collected separately for two leaves and a bud, third leaves, mature leaves and maintenance leaves. Tea plant was later uprooted from each plot cut and partitioned into all two leaves and a bud, all other leaves, green branches, brown branches; stem, hairy roots and other roots. Their wet and dry weight; N, and $\mathrm{K}$ concentrations were determined using standard procedures i.e. Concentrations of nitrogen and potassium were expressed on a dry weight basis and the nutrient 
Table 1. Monthly total rainfall, maximum, minimum and mean air temperature, soil temperature and relative humidity at Kangaita.

\begin{tabular}{|c|c|c|c|c|c|c|}
\hline Month & $\begin{array}{l}\text { Total Rainfall } \\
\qquad(\mathrm{mm})\end{array}$ & $\begin{array}{c}\text { Max. Air Temp. } \\
\left({ }^{\circ} \mathrm{C}\right)\end{array}$ & $\begin{array}{c}\text { Min. Air Temp. } \\
\left({ }^{\circ} \mathrm{C}\right)\end{array}$ & $\begin{array}{c}\text { Mean Air Temp. } \\
\left({ }^{\circ} \mathrm{C}\right)\end{array}$ & Soil Temp. $\left({ }^{\circ} \mathrm{C}\right)$ & RH (\%) \\
\hline Sep. & 41.6 & 19.2 & 9.9 & 14.6 & 18.1 & 87 \\
\hline Oct. & 148.9 & 20.8 & 11.4 & 16.1 & 20.1 & 83 \\
\hline Nov. & 146.4 & 20.2 & 10.4 & 15.3 & 18.9 & 90 \\
\hline Dec. & 48.4 & 21.4 & 9.3 & 15.4 & 20.9 & 77 \\
\hline Jan. & 29.7 & 21.9 & 8.7 & 15.3 & 21.6 & 67 \\
\hline Feb. & 15 & 21 & 10.3 & 15.7 & 21.8 & 56 \\
\hline Mar. & 76.2 & 22 & 12.8 & 17.4 & 22.4 & 62 \\
\hline Apr. & 290.7 & 20.7 & 15.1 & 17.9 & 19.6 & 69 \\
\hline May & 486.5 & 20.9 & 15.1 & 18 & 17.7 & 77 \\
\hline Jun. & 57.7 & 15 & 12.3 & 13.7 & 17.9 & 88 \\
\hline Jul. & 46.5 & 18.8 & 11.7 & 15.3 & 17.6 & 74 \\
\hline Aug. & 110.3 & 17.6 & 12 & 14.8 & 16.3 & 75 \\
\hline Mean & 124.8 & 20.0 & 11.6 & 15.8 & 19.4 & 75.4 \\
\hline
\end{tabular}

uptake and accumulation were calculated as the product of concentration and dry weight.

Plots yield data (buds and two leaves) were obtained monthly for a period of one year. The plot wise monthly yield data were converted into made tea per hectare, using the formula:

$\mathrm{MTY}=\left(\right.$ Green leaf weight ${ }^{*}$ No. of bushes per hectare *0.225)/(No. of bushes per Plot) Equation (1).

0.225 is a factor converting green leaf to made tea.

\subsection{Laboratory Methods}

\subsubsection{Chemical Analysis of Nitrogen in Soil}

Ammonium and nitrate nitrogen concentrations in the soils were determined by extraction of $10 \mathrm{~g}$ of the samples using $50 \mathrm{ml}$ of $2 \mathrm{M}$ potassium chloride solution [5,6]. After shaking in a reciprocal shaker for one hour, the extracts were filtered through Whatman No. 2 filter paper and the filtrate were used for the analysis of Ammonium and Nitrate $\mathrm{N}$. Distillate of $\mathrm{NH}_{4}-\mathrm{N}$ were generated by digesting $10 \mathrm{ml}$ of the soil samples filtrates using $\mathrm{MgO}$ and $\mathrm{NH}_{3}-\mathrm{N}$ after addition of devarda's alloy. The distillates were collected by $50 \mathrm{ml}$ conical flasks and titrated using $0.005 \mathrm{M} \mathrm{H}_{2} \mathrm{SO}_{4}$.

\subsubsection{Chemical Analysis of Nitrogen in Tea Partitions}

Total nitrogen concentrations were determined by the Micro-Kjeldahl method [5]. $0.1 \mathrm{~g}$ of milled samples were digested for an hour in concentrated $\mathrm{H}_{2} \mathrm{SO}_{4}$ plus $1 / 4$ catalyst tablet. After cooling, the digests were made alkaline with $40 \% \mathrm{NaOH}$ solution and the $\mathrm{NH}_{3}$ distilled were collected in $10 \mathrm{ml}$ boric acid containing mixed indicator.Total $\mathrm{N}$ were determined by titrating the distillates against $0.035 \mathrm{M} \mathrm{HCl}$.

\subsubsection{Chemical Analysis of Potassium in Soil}

The remaining soil samples were air-dried and then passed through a $2 \mathrm{~mm}$ sieve.

Potassium concentrations in the soils were determined by extraction of $10 \mathrm{~g}$ of the samples using $50 \mathrm{ml}$ of $1 \mathrm{M}$ ammonium nitrate solution. After shaking in a reciprocal shaker for thirty minutes, the extracts were filtered through Whatman No. 2 filter paper and the filtrates were used for the analysis of $\mathrm{K}$. Concentrations of $\mathrm{K}$ were determined using flame Photometer [6,7].

\subsubsection{Chemical Analysis of Potassium in Tea Partitions}

Exactly $0.25 \mathrm{~g}$ of the dried and ground tea leaf samples were ashed for four hours and then digested using 2 parts of $1: 1$ mixture of concentrated HNO3 (69\% - 70.5\%) and concentrated $\mathrm{HCl}(37 \%)$ under reflux to 3 parts of hydrogen peroxide. Concentrations of $\mathrm{K}$ in the digests were then determined using flame Photometer [7].

\subsection{Nutrient Budget Calculations}

Nutrient budgets were calculated using plant dry matter weights in aboveground plant, pluckable shootsand root$\sin \mathrm{Kg} \cdot \mathrm{ha}^{-1}$. Nutrient content in the aboveground plant, pluckable shoots and roots, was determined by multiplying percentnutrient content by dry matter content weight. 


\subsection{Statistical Analysis}

The data were subjected to the analysis of variance (ANOVA) using the MSTATC software package [8]. In case of significant treatment effects, a comparison of means was performed by means of least significant difference (LSD) method at a significance level of 5\% (P = $0.05)$. Use of difference between treatments implies statistical difference $(\mathrm{P}=0.05)$ while no difference implies no statistical difference.

\section{Results and Discussion}

\subsection{Dynamics of Nitrogen and Potassium in Tea}

Plant tissue analysis provided a mean of assessing the plant uptake, and removal from the soil, of $\mathrm{N}$ and $\mathrm{K}$.

\subsubsection{Nitrogen Concentration in Tea Plant Tissues}

Nitrogen concentrations of two leaves and a bud, third, mature and maintenance leaves, green and brown branches, stem, hairy and other roots were determined and their results are given in Table 2 below.

Different nitrogen rates, potassium rates and their interactions had insignificant effecton two leaves and a bud, third leaves; green branches, brown branches, stem, hairy roots and other roots nitrogen nutrient concentrations (Table 2). They were almost similar within all ratios. Increased nitrogen rates had significantly varied nitrogen nutrient concentrations inmatureand maintenanceleaves. Increased potassium rates significantly reduced nitrogen nutrient concentrations inmaintenanceleaves from 2.95 to 2.54 percent.
From the table, it is clear that nitrogen content were high in young leaves than old ones. This reflects the fact that nitrogen is highly mobile and is often translocated from old leaves to young leaves [9]. It has been reported for other crops, that plants allocate nitrogen to the youngest leaves in order to maintain a high-rate of canopy photosynthesis [10]. Indeed, the nitrogen content of "two leaves and a bud" is less sensitive to nitrogen fertilization; hence, the use of the mature leaf for the diagnosis of the nutrient status of tea bushes is recommended in East Africa [11]. Cultivated tea is maintained as a low bush in a continuous vegetative phase with regular removal of the young shoots. For annual crops, nitrogen uptake is regulated by the crop dry mass accumulation under non-limiting nitrogen supply within species and across environments [12].

\subsubsection{Potassium Concentration in Tea Plant Tissues}

Potassium concentrations of two leaves and a bud, third, mature and maintenance leaves, green and brown branches, stem, hairy and other roots were determined and their results are given in Table 3 below.

There was significant variation in potassium concentrations among the different Nitrogen rates, potassium rates and their interactions except two leaves and a bud, green branches and stems (Table 3). Increased nitrogen rates from 0 to $200 \mathrm{Kg} \mathrm{N} \cdot \mathrm{ha}^{-1} \cdot \mathrm{yr}^{-1}$ significantly reduced potassium nutrient concentrations inmature leaves from 2.6 to 2.1 percent, had varied effect on brown branches and increased potassium nutrient concentrations inother roots from 0.65 to 0.74 percent (Table 3 ). Generally, potassium content in third, mature and maintenance leaves

Table 2. Effect of $\mathrm{N}$ and $\mathrm{K}$ interaction on plant partitions nutrient $\mathrm{N}(\%)$.

\begin{tabular}{|c|c|c|c|c|c|c|c|c|c|}
\hline Treatments & 2 leaves + Bud & $\begin{array}{c}\text { 3rd } \\
\text { leaves }\end{array}$ & $\begin{array}{l}\text { Mature } \\
\text { leaves }\end{array}$ & $\begin{array}{c}\text { Maintenance } \\
\text { leaves }\end{array}$ & $\begin{array}{c}\text { Green } \\
\text { Branches }\end{array}$ & $\begin{array}{c}\text { Brown } \\
\text { Branches }\end{array}$ & Stem & $\begin{array}{l}\text { Hairy } \\
\text { Roots }\end{array}$ & $\begin{array}{l}\text { Other } \\
\text { roots }\end{array}$ \\
\hline $\mathrm{N}_{0} \mathrm{~K}_{0}$ & 4.49 & 3.25 & $2.59^{\mathrm{ab}}$ & $2.92^{\mathrm{abc}}$ & 2.30 & 0.58 & 0.31 & 1.59 & 0.30 \\
\hline $\mathrm{N}_{0} \mathrm{~K}_{1}$ & 4.49 & 3.09 & $2.77^{\mathrm{a}}$ & $2.64^{\mathrm{cd}}$ & 1.55 & 0.45 & 0.33 & 1.68 & 0.29 \\
\hline $\mathrm{N}_{0} \mathrm{~K}_{2}$ & 4.86 & 3.38 & $2.33^{\mathrm{bc}}$ & $2.37^{\mathrm{de}}$ & 1.83 & 0.40 & 0.38 & 1.57 & 0.31 \\
\hline $\mathrm{N}_{1} \mathrm{~K}_{1}$ & 4.78 & 3.54 & $2.11^{\mathrm{c}}$ & $2.34^{\mathrm{e}}$ & 1.83 & 0.52 & 0.39 & 1.70 & 0.34 \\
\hline $\mathrm{N}_{1} \mathrm{~K}_{2}$ & 4.54 & 3.18 & $2.12^{\mathrm{c}}$ & $2.44^{\mathrm{de}}$ & 2.04 & 0.55 & 0.34 & 1.76 & 0.30 \\
\hline $\mathrm{N}_{2} \mathrm{~K}_{0}$ & 4.69 & 3.50 & $2.72^{\mathrm{a}}$ & $3.09^{\mathrm{a}}$ & 2.28 & 0.55 & 0.45 & 1.84 & 0.49 \\
\hline $\mathrm{N}_{2} \mathrm{~K}_{1}$ & 4.78 & 3.62 & $2.74^{\mathrm{a}}$ & $2.97^{\mathrm{ab}}$ & 2.03 & 0.60 & 0.36 & 1.39 & 0.45 \\
\hline CV $(\%)$ & 9.10 & 7.76 & 12.26 & 10.92 & 21.41 & 12.65 & 17.99 & 13.47 & 26.11 \\
\hline $\operatorname{LSD}(5 \%)$ & ns & ns & 0.218 & 0.209 & ns & ns & ns & ns & ns \\
\hline
\end{tabular}

$\left(\mathrm{N}_{0}=0 ; \mathrm{N}_{1}=100 ; \mathrm{N}_{2}=200\right) \mathrm{Kg} \mathrm{N} \cdot \mathrm{ha}^{-1} \cdot \mathrm{yr}^{-1} ;\left(\mathrm{K}_{0}=0 ; \mathrm{K}_{1}=40 ; \mathrm{K}_{2}=80\right) \mathrm{Kg} \mathrm{K}_{2} \mathrm{O}$ ha $^{-1} \cdot \mathrm{yr}^{-1}, \mathrm{CV}=$ Coefficient of variation, ns $=$ not significant, ${ }^{*}$ each row with same letters was not significantly different $(\mathrm{P}<0.05)$. 
Table 3. Effect of $\mathrm{N}$ and $\mathrm{K}$ interaction on plant partitions nutrient $\mathrm{K}$.

\begin{tabular}{|c|c|c|c|c|c|c|c|c|c|}
\hline Treatments & 2 leaves + Bud & $\begin{array}{c}\text { 3rd } \\
\text { leaves }\end{array}$ & $\begin{array}{l}\text { Mature } \\
\text { leaves }\end{array}$ & $\begin{array}{l}\text { Maintenance } \\
\text { leaves }\end{array}$ & $\begin{array}{c}\text { Green } \\
\text { Branches }\end{array}$ & $\begin{array}{c}\text { Brown } \\
\text { Branches }\end{array}$ & Stem & $\begin{array}{l}\text { Hairy } \\
\text { Roots }\end{array}$ & $\begin{array}{l}\text { Other } \\
\text { roots }\end{array}$ \\
\hline $\mathrm{N}_{0} \mathrm{~K}_{0}$ & 2.77 & $2.58^{\mathrm{ab}}$ & $2.37^{\mathrm{ab}}$ & $2.77^{\mathrm{a}}$ & 1.93 & $0.72^{\mathrm{a}}$ & 0.50 & $1.05^{\mathrm{ab}}$ & $0.59^{\mathrm{cd}}$ \\
\hline $\mathrm{N}_{0} \mathrm{~K}_{1}$ & 2.33 & $3.18^{\mathrm{ab}}$ & $2.65^{\mathrm{a}}$ & $2.60^{\mathrm{ab}}$ & 2.18 & $0.58^{\mathrm{ab}}$ & 0.50 & $0.91^{\mathrm{ab}}$ & $0.66^{\mathrm{c}}$ \\
\hline $\mathrm{N}_{0} \mathrm{~K}_{2}$ & 3.01 & $3.20^{\mathrm{ab}}$ & $2.83^{\mathrm{a}}$ & $2.93^{\mathrm{a}}$ & 2.41 & $0.59^{\mathrm{ab}}$ & 0.58 & $1.24^{\mathrm{ab}}$ & $0.71^{\mathrm{bc}}$ \\
\hline $\mathrm{N}_{1} \mathrm{~K}_{0}$ & 2.37 & $2.77^{\mathrm{ab}}$ & $2.10^{\mathrm{ab}}$ & $2.59^{\mathrm{ab}}$ & 2.26 & $0.59^{\mathrm{ab}}$ & 0.50 & $1.29^{\mathrm{a}}$ & $0.63^{\mathrm{cd}}$ \\
\hline $\mathrm{N}_{1} \mathrm{~K}_{1}$ & 2.58 & $3.03^{\mathrm{ab}}$ & $2.65^{\mathrm{a}}$ & $2.72^{\mathrm{a}}$ & 2.42 & $0.72^{\mathrm{a}}$ & 0.66 & $1.04^{\mathrm{ab}}$ & $0.72^{\mathrm{bc}}$ \\
\hline $\mathrm{N}_{1} \mathrm{~K}_{2}$ & 2.52 & $3.27^{\mathrm{a}}$ & $2.46^{\mathrm{ab}}$ & $2.57^{\mathrm{ab}}$ & 2.57 & $0.74^{\mathrm{a}}$ & 0.72 & $0.89^{\mathrm{ab}}$ & $0.69^{\mathrm{bc}}$ \\
\hline $\mathrm{N}_{2} \mathrm{~K}_{0}$ & 2.31 & $2.40^{\mathrm{b}}$ & $1.72^{\mathrm{b}}$ & $2.16^{\mathrm{b}}$ & 2.05 & $0.42^{\mathrm{b}}$ & 0.47 & $0.61^{\mathrm{b}}$ & $0.52^{\mathrm{d}}$ \\
\hline $\mathrm{N}_{2} \mathrm{~K}_{1}$ & 2.77 & $3.14^{\mathrm{ab}}$ & $2.13^{\mathrm{ab}}$ & $2.74^{\mathrm{a}}$ & 2.43 & $0.66^{\mathrm{a}}$ & 0.66 & $1.05^{\mathrm{ab}}$ & $0.82^{\mathrm{ab}}$ \\
\hline $\mathrm{N}_{2} \mathrm{~K}_{2}$ & 2.58 & $3.26^{\mathrm{a}}$ & $2.46^{\mathrm{ab}}$ & $2.87^{\mathrm{a}}$ & 2.24 & $0.68^{\mathrm{a}}$ & 0.63 & $1.18^{\mathrm{ab}}$ & $0.88^{\mathrm{a}}$ \\
\hline $\mathrm{CV}$ & 11.05 & 9.51 & 11.30 & 6.92 & 16.24 & 11.35 & 15.89 & 21.73 & 7.15 \\
\hline \multicolumn{10}{|l|}{ LSD (5\%) } \\
\hline $\mathrm{N}$ & ns & ns & 0.19 & ns & ns & 0.05 & $\mathrm{~ns}$ & ns & 0.04 \\
\hline K & $\mathrm{ns}$ & 0.20 & 0.19 & 0.13 & $\mathrm{~ns}$ & 0.05 & 0.07 & $\mathrm{~ns}$ & 0.04 \\
\hline $\mathrm{N}^{*} \mathrm{~K}$ & ns & ns & $\mathrm{ns}$ & 0.23 & ns & 0.05 & ns & 0.27 & 0.06 \\
\hline
\end{tabular}

$\left(\mathrm{N}_{0}=0 ; \mathrm{N}_{1}=100 ; \mathrm{N}_{2}=200\right) \mathrm{Kg} \mathrm{N} \cdot \mathrm{ha}^{-1} \cdot \mathrm{yr}^{-1} ;\left(\mathrm{K}_{0}=0 ; \mathrm{K}_{1}=40 ; \mathrm{K}_{2}=80\right) \mathrm{Kg} \mathrm{K}_{2} \mathrm{O}$ ha $^{-1} \cdot \mathrm{yr}^{-1}, \mathrm{CV}=$ Coefficient of variation, ns $=$ not significant, ${ }^{*}$ each row with same letters was not significantly different $(\mathrm{P}<0.05)$.

in $\mathrm{K}_{2}\left(80 \mathrm{Kg} \mathrm{K}_{2} \mathrm{O}\right.$ ha $\left.^{-1} \cdot \mathrm{yr}^{-1}\right)$ treatments was more than $\mathrm{K}_{1}\left(40 \mathrm{Kg} \mathrm{K}_{2} \mathrm{O} \mathrm{ha}{ }^{-1} \cdot \mathrm{yr}^{-1}\right)$ and $\mathrm{K}_{0}$ (control) treatments as expected. Increased potassium rates from 0 to $80 \mathrm{Kg} \mathrm{K}_{2} \mathrm{O}$ $\mathrm{ha}^{-1} \cdot \mathrm{yr}^{-1}$ significantly increased potassium nutrient concentrations inthirdleaves from 2.6 to 3.2 percent, in mature leaves from 2.1 to 2.6 percent, in maintenance leaves from 2.5 to 2.8 percent, in brown branches from 0.58 to 0.67 percent, in stems from 0.49 to 0.64 percent and other roots from 0.58 to 0.76 percent.

The positive N-K interaction is also dependent on the form of nitrogen supplied. Nitrate uptake has been shown to stimulate net $\mathrm{K}^{+}$uptake in various crop species, suggesting that the $\mathrm{NO}_{3}{ }^{-}$ion serves as a mobile accompanying anion during $\mathrm{K}^{+}$uptake and/or transport [3]. It has been reported that $\mathrm{NH}_{4}^{+}$reduces $\mathrm{K}^{+}$uptake in plant roots [13] because $\mathrm{NH}_{4}^{+}$and $\mathrm{K}^{+}$have similar charges and hydrated diameters.

Mean $\mathrm{K}$ content in the tea leaves did not exhibit any deficiency trend even in the control plots (no fertilization) according to some guidelines issued by researchers [11] of 3 and 3.5 percent.

These findings supported the earlier by Kumar et al. [14] who reported a higher concentration of K and suggested that it might have been specifically incorporated within a binding ligand in the tea leaves. Dang [15] reported that plant nutrient concentrations in the tea plant are highest in the young leaves and buds with concentration ranges for the major nutrient element $\mathrm{K}$ of $2.3 \%$ -
$3.0 \%$. These ranges of values are highly consistent with the levels obtained in the leaves of the studied tea plants.

Moreover, these results indicated that the harvested tea, which involves mainly the young leaves and buds, represents a significant, permanent removal of potassium from the soil.

Potassium is highly mobile within plants but its flow and partitioning can change depending on the forms of nitrogen supply. $\mathrm{NH}_{4}{ }^{+}$nutrition in comparison to $\mathrm{NO}_{3}{ }^{-}$supply results in more $\mathrm{K}$ translocation to leaves.

\subsubsection{Fertilizer Additions, Tea Plant Nutrient Removals and Storage}

Nutrient budget assessment serves as an effective tool for estimating the magnitude of nitrogen loss/gain of the agro-eco systems and to appraise their sustainability. It brings forth awareness of soil fertility problems, besides providing information relating to the resultant release of some nutrients e.g. nitrogen into the environment consequent to agricultural practices. Quantitative information relating to the nutrient escape into the environment can be gainfully utilized for identification of causative factors, enhancing fertilizer use efficiency and formulating strategies aimed at plugging the leakages.

Nitrogen and potassium rates per tea plant multiplied by the total number of tea plants per hectare $(13,448)$ when the same spacing is used divided by total number of tea plants per plot (1350) gave the total fertilizer added. 
Mean for the nitrogen and potassium concentrations of two leaves and a bud (Tables 2 and 3) were multiplied by total plucked yield for the research period converted to made tea to get $\mathrm{N}$ and $\mathrm{K}$ removed through harvest (Figure 2 and Table 4).

Mean for the nitrogen and potassium concentrations of third, mature and maintenance leaves, green and brown branches, stem, hairy and other roots in Tables $\mathbf{2}$ and $\mathbf{3}$ were multiplied by their oven dried weight to get $\mathrm{N}$ and $\mathrm{K}$ stored in these plant parts i.e. the nutrient concentration in the whole plant is calculated using Equation (2) below.

Nutrient concentration $=[($ foliage dry weight $\times$ foliage nutrient concentration $)+($ frame dry weight $\times$ frame nutrient concentration $)+($ root dry weight $\times$ root nutrient concentration) $] \div$ (foliage dry Weight + frame dry weight
+ root dry weight) Equation (2).

Therefore, the amount of nutrients removed by tea is a function of the biomass yield multiplied by the nutrient level in the biomass.

The annual $\mathrm{N}$ and $\mathrm{K}$ uptake in harvested tea ranged from 59.96 and 30.50 to 64.47 and $37.24 \mathrm{Kg} \cdot \mathrm{ha}^{-1}$ respectively (Table 4). These values are $5-10 \mathrm{Kg} \cdot \mathrm{ha}^{-1}$ higher than those reported by De Costa et al. [16] for Sri Lanka. The high $\mathrm{N}$ uptake by harvested shoots reflects the high productivity of the tea plantations in Kenya.

Plant tissue nutrient concentrations also reflected the availability of soil nutrients and, thus, were useful indicators of soil nutrient deficiency [3]. Indeed, Epstein [17] suggested that nutrient concentrations in mature leaves could be used as indicators for soil deficiencies of

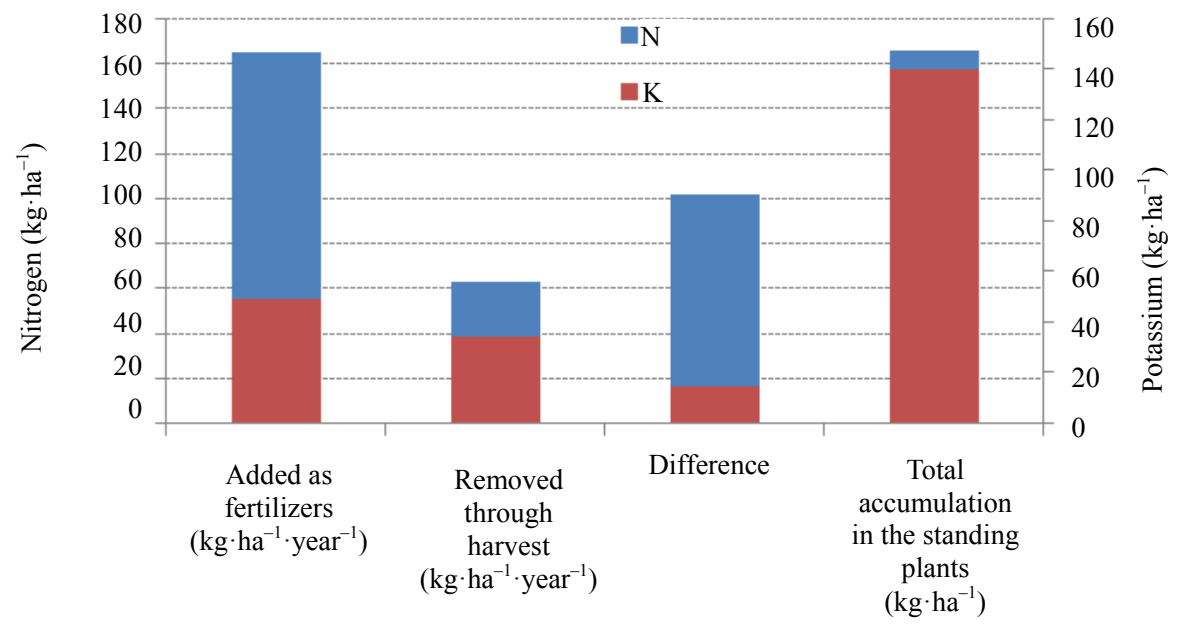

Figure 2. Fertilizer additions, tea plant nutrient removals and storage.

Table 4. Nutrient budget of tea plant removals, storage, additions and excess.

\begin{tabular}{|c|c|c|c|c|c|c|c|c|}
\hline \multirow[t]{2}{*}{ Treatment } & \multicolumn{2}{|c|}{$\begin{array}{l}\text { Fertilizer applied } \\
\qquad\left(\mathrm{Kg}^{-} \mathrm{ha}^{-1}\right)\end{array}$} & \multicolumn{2}{|c|}{$\begin{array}{l}\text { Nutrient uptake } \\
\left(\mathrm{Kg}^{-h^{-1}}\right)\end{array}$} & \multicolumn{2}{|c|}{$\begin{array}{l}\text { Storage standing plants } \\
\left(\mathrm{Kg}^{\left.-\mathrm{ha}^{-1}\right)}\right.\end{array}$} & \multicolumn{2}{|c|}{$\begin{array}{l}\text { Excess } \\
\left(\mathrm{Kg}^{-h^{-1}}\right)\end{array}$} \\
\hline & $\mathrm{N}$ & $\mathrm{K}$ & $\mathrm{N}$ & $\mathrm{K}$ & $\mathrm{N}$ & $\mathrm{K}$ & $\mathrm{N}$ & $\mathrm{K}$ \\
\hline $\mathrm{N}_{0} \mathrm{~K}_{0}$ & 0 & 0 & 60.10 & 37.24 & 103.03 & 98.76 & - & - \\
\hline $\mathrm{N}_{0} \mathrm{~K}_{1}$ & 0 & 40 & 60.52 & 31.26 & 98.83 & 102.98 & - & 8.74 \\
\hline $\mathrm{N}_{0} \mathrm{~K}_{2}$ & 0 & 80 & 61.24 & 35.36 & 103.56 & 117.73 & - & 44.64 \\
\hline $\mathrm{N}_{1} \mathrm{~K}_{0}$ & 100 & 0 & 64.47 & 31.85 & 100.59 & 101.90 & 35.53 & - \\
\hline $\mathrm{N}_{1} \mathrm{~K}_{1}$ & 100 & 40 & 64.18 & 34.45 & 96.95 & 109.09 & 35.82 & 5.55 \\
\hline $\mathrm{N}_{1} \mathrm{~K}_{2}$ & 100 & 80 & 60.99 & 33.92 & 101.32 & 110.44 & 39.01 & 46.08 \\
\hline $\mathrm{N}_{2} \mathrm{~K}_{0}$ & 200 & 0 & 63.02 & 31.21 & 110.22 & 88.70 & 136.98 & - \\
\hline $\mathrm{N}_{2} \mathrm{~K}_{1}$ & 200 & 40 & 64.23 & 37.20 & 105.53 & 110.42 & 135.77 & 2.80 \\
\hline $\mathrm{N}_{2} \mathrm{~K}_{2}$ & 200 & 80 & 59.96 & 30.50 & 96.51 & 113.47 & 140.04 & 49.50 \\
\hline
\end{tabular}

$\left(\mathrm{N}_{0}=0 ; \mathrm{N}_{1}=100 ; \mathrm{N}_{2}=200\right) \mathrm{Kg} \mathrm{N} \cdot \mathrm{ha}^{-1} \cdot \mathrm{yr}^{-1} ;\left(\mathrm{K}_{0}=0 ; \mathrm{K}_{1}=40 ; \mathrm{K}_{2}=80\right) \mathrm{Kg} \mathrm{K}_{2} \mathrm{O} \mathrm{ha}{ }^{-1} \cdot \mathrm{yr}^{-1}$. 
the plant-mobile nutrients, whereas young leaves could be used as indicators for soil deficiencies of the less mobile nutrients.

For a sustainable production system the nutrients removed should be at the very least be replaced. If nutrients are not replaced the soil reserves are slowly depleted and soil fertility declines. This can lead to nutrient deficiencies and reduced growth.

From Figure 2, fertilizer inputs ( $\mathrm{N}$ and $\mathrm{K}$ ) generally surpassed the amount of nutrients removed with the harvested tea. An estimated nutrient balance (inputs-outputs) was calculated by assuming that 1) over the short-term (i.e. one year), there were no nutrients recycled as plant prunings; and 2) the amount of nutrients sequestered in the standing crop during the year was generally small [2]. Thus, it appears that crop nutrient demands are generally met, or exceeded, by fertilizer inputs.

The nutrients stored in the standing biomass represent a loss from the soil (though they will eventually be returned to the soil when the plantation is no longer economically viable and the stands are cut down). The nutrients removed with the harvest also are considered to be lost from the soil. Only the nutrients in the prunings are returned to the soil and, together with fertilizer additions, are essential to maintaining the fertility status of the soil and, in turn, tea productivity.

The nutrient concentration calculation (Equation (2)) does not take into account soils existing nutritional status. However, it is still a good estimate of fertilizer requirements and highlights any major discrepancies between fertilizer inputs and crop removal.

\section{Conclusion}

This study measured nitrogen and potassium dynamics of strongly acidic soilin Kangaita using clone TRFK 11-4. Fertilizer rates had significant effect on tissue concentrationsof nitrogen and potassium.Increased nitrogen rates had significantly varied nitrogen nutrient concentrations inmatureand maintenanceleaves. Increased potassium rates significantly reduced nitrogen nutrient concentrations inmaintenanceleaves from 2.95 to 2.54 percent. Generally, potassium content in third, mature and maintenance leaves in $\mathrm{K}_{2}\left(80 \mathrm{Kg} \mathrm{K}_{2} \mathrm{O} \mathrm{ha}{ }^{-1} \cdot \mathrm{yr}^{-1}\right)$ treatments was more than $\mathrm{K}_{1}\left(40 \mathrm{Kg} \mathrm{K}_{2} \mathrm{O} \mathrm{ha}^{-1} \cdot \mathrm{yr}^{-1}\right)$ and $\mathrm{K}_{0}$ (control) treatments as expected. The annual $\mathrm{N}$ and $\mathrm{K}$ uptake in harvested tea ranged from 59.96 and 30.50 to 64.47 and $37.24 \mathrm{Kg} \mathrm{ha}^{-1}$ respectively. Fertilizer inputs generally surpassedthe crop nutrient demands (nutrient loss from harvest). However, if some other factors (e.g. nutrient leaching, storage in the plants) are accounted for within the totalnutrient budget, these inputs of fertilizer may notbe sufficient to balance total nutrient losses.

\section{REFERENCES}

[1] K. Mengel and E. A. Kirby, "Principles of Plant Nutrition," IPI Publication, Bern, 1987.

[2] N. Q. Do, T. T. N. Vo and K. T. Vi, "Results of Experiment: Chemical Fertilizers (NPK) on Tea Crop in Phu Ho," In: Agricultural Research, Agricultural Publishing House, Hanoi, 1980, pp. 127-146 (in Vietnamese).

[3] R. W. Pearcy, J. R. Ehleringer, H. A. Mooney and P. W. Rundel, "Plant Physiological Ecology: Field Methods and Instrumentation," Chapman \& Hall, New York, 1989, pp. 185-205.

[4] Tea Board of Kenya, "Kenya Tea Industry Performance Highlights for 2010 and Outlook for 2011," 2011.

[5] J. M. Bremner and C. S. Mulveney, "Nitrogen Total," In A. L. page, Ed., Methods of Soil Analysis. Agron. No. 9, Part 2: Chemicals and Microbiological Properties, 2nd Edition, American Society of Agronomy, Madison, 1982, pp. 595-624.

[6] K. H. Tan, "Soil Sampling Preparation and Analysis," Marcel Dekker, New York, 1996.

[7] A. G. Spencer, "Flame Photometry," Lancet, Vol. 2, No. 6639, 1950, pp. 623-627.

[8] F. Russel, "MSTATC Computer Based Statistical Software Package," 1995.

[9] H. Marschner, "Mineral Nutrient of Higher Plants," 2nd Edition, Academic Press, London, 1995, pp. 106-130.

[10] G. Lemaire and F. Gastal, "N Uptake and Distribution in Plant Canopies," In: G. Lemaire, Ed., Diagnosis of the Nitrogen Status in Crops, Springer-Verlag, Berlin, 1997, pp. 3-43. doi:10.1007/978-3-642-60684-7 1

[11] C. O. Othieno, "Summary of Recommendations and Observations from TRFK," Tea, Vol. 9, No. 2, 1988, pp. 50-65.

[12] G. Lemaire, E. van Oosterom, J. Sheehy, M. H. Jeuffroy, A. Massignam and L. Rossato, "Is Crop N Demand More Closely Related to Dry Matter Accumulation or Leaf Area Expansion during Vegetative Growth?" Field Crops Research, Vol. 100, No. 1, 2007, pp. 91-106. doi:10.1016/j.fcr.2006.05.009

[13] D. C. Gowdin and C. A. Jones, "Nitrogen Dynamics in Soil Plant Systems," In: Modeling Plant and Soil Systems, Agronomy Monograph No. 31, 1991, pp. 287-321.

[14] A. Kumar, A. G. C. Nair, A. V. R. Reddy and A. N. Garg, "Availability of Essential Elements in Indian and US Tea Brands," Food Chemistry, Vol. 89, No. 3, 2005, pp. 441448. doi:10.1016/i.foodchem.2004.03.003

[15] M. V. Dang, "Soil-Plant Nutrient Balance of Tea Crops in the Northern Mountainous Region, Vietnam," Agriculture, Ecosystems and Environment, Vol. 105, No. 1-2, 2005, pp. 413-418.

[16] W. A. J. M. De Costa, P. Surenthran and K. B. Attanayake, "Tree-Crop Interactions Inhedgerow Intercropping with Different Tree Species and Tea in Sri Lanka. 2. Soiland Plant Nutrients," Agroforestry Systems, Vol. 63, No. 3, 2005, pp. 211-218.

[17] E. Epstein, "Mineral Nutrition of Plants: Principles and Perspectives," Wiley, New York, 1972, pp. 15-79. 